\title{
White Means Never Having TO SAY You're Sorry The Racial Project in Explaining Mass Shootings
}

\author{
William Mingus \\ University of Illinois, Chicago \\ BRADLEY ZOPF \\ University of Illinois, Chicago
}

\begin{abstract}
Mass shootings, such as the ones that occurred at Columbine, Virginia Tech, Northern Illinois University, and Fort Hood receive considerable attention in the public arena. Though race is seldom highlighted as a significant consideration in mass shootings, this paper considers the way in which the race of the perpetrator influences the response of the media and the public to these tragedies. Mass shootings are viewed through the lens of Omi and Winant's (1994) racial formation theory. The prominence given to the race of the perpetrator when the shooter is of any race but white and the deliberate omission of race in discussions of white shooters suggests a racial project that results in both white privilege and an opposing "forever foreigner" status for non-whites.
\end{abstract}

\footnotetext{
William Mingus is a graduate student at the University of Illinois at Chicago. His research interests focus on identity formation issues of marginalized populations, particularly those marginalized as a result of a discreditable or hidden stigma. Bradley Zopf is also a graduate student at the University of Illinois at Chicago. His research interests include race/ethnicity and social theory with a particular emphasis on the ways in which Arab-Americans negotiate their racial and ethnic position. Contact can be directed to William atwmingu2@uic.edu and Bradley at bzopf2@uic.edu.
} 


\section{Introduction}

On April 16, 2007, a man entered Norris Hall where classes were underway at Virginia Polytechnic Institute and State University (more commonly known as Virginia Tech) in Blacksburg, Virginia. Armed with two hand guns, this man opened fire, expending more than 200 rounds, unleashing a fury of violence that would leave 32 people dead and many more wounded and finally taking his own life. The man was later identified as Seung-Hui Cho, a Korean-born, U.S. permanent resident and a student at Virginia Tech. Within days, a Korean official issued a statement on behalf of all Koreans who had "taken it upon themselves to apologize for the actions of gunman Cho Seung Hui, citing a sense of collective guilt and shame simply by virtue of a shared ethnicity" (Hong 2007).

A little less than one year later, on February 14, 2008, another man entered Cole Hall at Northern Illinois University (NIU) in DeKalb, Illinois. Armed with a shotgun and three handguns, he walked onto a stage at the front of a large classroom and began firing at students - six shots with the shotgun and forty-eight with the handguns. Six students were killed and eighteen were injured during the shooting spree. His final bullet ended his own life (Vann 2008). The shooter was identified as Steven Kazmierczak, a former graduate student from NIU. Like most mass school shooters, Kazmierczak was white. No apology was issued.

On November 5, 2009, an army officer began shooting at other soldiers at Fort Hood army base in Texas. Armed with two handguns, the officer fired more than 100 rounds, killing thirteen and wounding another thirty. His shooting rampage stopped when he was shot by civilian police officers. The shooter survived and was identified as Major Nidal Malik Hasan, an American-born son of immigrant parents from a small Palestinian town near Jerusalem (Dao 2009). Hasan was also Muslim. Within days of the shooting, Muslims and Arabs alike began "bracing themselves for a wave of anger and attacks after news broke on Thursday that the primary suspect behind the shooting deaths of twelve soldiers at Fort Hood had a Arabic and/or Muslim-sounding name" (Stein 2009).

In this paper, we consider the ways in which mass shootings 
contitute a racial project. In particular, we examine how the race of the perpetrator influences the response of the media and the public. The prominence given to the race of the perpetrator when the shooter is anything but white and the deliberate omission of race in discussions of white shooters invites discourse on the marked disparity. Mass shootings, viewed through the lens of racial formation theory (Omi and Winant 1994), are racial projects that simultaneously reinforce white privilege and reconstruct an opposing 'forever foreigner' status for non-whites (O'Brien 2008).

\section{Mass Shootings}

Gun violence is a daily occurrence in the United States. Shootings occur with alarming frequency, often in the form of gang violence, during robberies or other forms of violence targeting specific individuals (Ross 2009). Less common, though certainly more frequently in the past two decades, are mass shootings. Mass shootings are differentiated from other forms of gun violence by the fact that the victims are generally randomly targeted by perpetrators. For the purposes of this paper, the definition of mass shootings will be a modified version of a definition suggested by Langman (2009) who said that "rampage school shootings occur when students or former students attack their own schools" (p. 2). This is consistent with the criteria used by Newman and Fox (2004) in defining a rampage shooting. Although not involving a school, the recent Fort Hood shooting shared many of the characteristics of school shootings; thus, the definition of a mass shooting used here will include any shooting that involves a member or former member of a particular group that attacks other members of that group, where multiple victims are chosen apparently at random by the perpetrator, and where guns are the principle weapon used in the attack. The incident at Fort Hood, which was carried out by an army officer against other army personnel, falls under this definition.

Mass school-shootings are not a new phenomenon. In 1966, Charles Whitman, a student at the University of Texas in Austin, climbed a clock tower at the school and began shooting. His rampage took the lives of thirteen people and wounded thirty-three more (Kolchak 2006). Newman et al. (2004) identified twenty- 
eight mass school-shootings between 1974 and 2002 and described another nine that occurred between 2002 and 2008 (Newman and Fox 2009). The majority of the shooters were white with few notable exceptions. ${ }^{1}$

\section{Data and Methods}

This paper will focus on four shootings, two of which were committed by individuals identified as white and two by individuals identified as non-white. The incidents discussed here took place at Columbine High School, Northern Illinois University, Virginia Tech, and Fort Hood, respectively. These four incidents were chosen for this paper for several reasons. First, the juxtaposition of these particular events illustrates the varying role that race plays in official and media responses to the killings. Because most mass shooting involve perpetrators who are white, drawing on the Virginia Tech and Fort Hood shootings provided a unique glimpse into tragedies committed by non-whites. Second, each of these events occurred within the past decade, giving them more contemporary relevance. Finally, these particular events were chosen in part because each attracted a high level of media attention. Although any mass shooting is newsworthy, each of the four incidents used here became pre-eminent national news stories that captured the attention of the American public. Although we believe that the findings presented here would hold true in any of the mass shootings over the past quarter century, this becomes an empirical question. Because we did not draw a random sample of mass shootings, we do not mean to suggest that these results are necessarily generalizable beyond the specific incidents chosen.

The purpose of this paper is to assess whether public and media reaction to mass shootings constitutes a type of racial project as described by Omi and Winant (1994). Data for this assessment were gathered by culling official reports or news stories related to the individual incidents looking for any mention of race, either directly or indirectly. Direct references are those that explicitly identified the race of the perpetrator, whereas indirect references might

\footnotetext{
${ }^{1}$ According to Kimmel and Mahler (2003), since 1992 only one random school shooting was committed by a Black perpetrator.
} 
include those that used "code words" to identify the perpetrator's race (Bonilla-Silva 2006). Because theories of whiteness suggest that people often fail to see "white" as a race (Frankenberg 1993), official reports and news stories that fail to mention race at all are just as significant as those that do include this information.

\section{Understanding Race}

Before making a claim that race plays a significant role in the responses to mass shootings, it would be helpful to define what is meant by the term race. This, in itself, is a question easier asked than answered. Although race was at one time considered to be based on biological difference, most scholars today view race as a social construct (Nagel 1994). Racial categories are generally based on phenotypical differences, the most obvious being skin color. Van Den Berghe (2001) conjectured that the categorization of individuals originated from a nepotistic need to defend familial ties, or blood lines. Through the passage of time and as a result of intermarriage, these blood lines became less clearly defined and were often conflated with ethnicity (Cornell and Hartmann 2006; Winant 2000). Today, the terms race and ethnicity are often used interchangeably in common vernacular. In fact, some argue that race is so historically laden with inaccurate and persistent implications that we should do away with the term altogether (Fields 1990; Montagu 1962).

The historical significance of race is important in understanding the way in which race affects any interpretation of shooting rampages. Though phenotypical differences between humans have existed since at least the advent of written history, race as a concept can be understood as a more contemporary development associated with the arrival of Europeans in the Americas. The discovery of people who looked and acted differently led to a religious crisis among Europeans who were suddenly forced to "reconcile the various Christian metaphysics with the existence of peoples who were more 'different' than any whom Europe had previously known" (Omi and Winant 1994:62). Similarly, Fields (1990) believes that race was invented in order to justify the unequal treatment and enslavement of a particular group of 
people in a land that prided itself on "freedom and justice for all." Slavery caused ideological dissonance for Americans, and whites sought to resolve this dissonance through the creation of race, a designation of one group of people as naturally inferior to another. Racist ideology based on moral or religious tenants evolved into a scientific ideology, one that supported the notion of biological differences between people of different races and the inherent superiority of whites over non-whites (Omi and Winant 1994). This ideology of racism, like any other ideology, is reinforced and reproduced through rituals. Fields (1990) suggests that, contrary to what many claim, an ideology does not have a life of its own but must instead be affirmed by a perpetuation of rituals handed down and replicated by successive generations. She concludes that the reason that racism continues is "because we continue to create it today" (Fields 1990:117). This suggests that race, and therefore racial categories, are not static, but are constantly created and recreated by the societies in which they exist.

This idea that race is constantly created and recreated by society was more clearly delineated by Omi and Winant (1994) in their theory of racial formation. Recognizing the importance of taking into account the history of race relations, racial formation theory can be defined as "the sociohistorical process by which racial categories are created, inhabited, transformed, and destroyed" (Omi and Winant 1994:180). Racial formation can best be understood as a series of macro- and micro-level social processes resulting in historically situated racial projects. As such, "racial projects link significations or representations of race, on the one hand, with social structural manifestations of racial hierarchy or dominance, on the other" (Winant 2001:100). Macro-level projects include a neoconservative color-blind project where race is assumed to be ignored, though in reality it is simply replaced by code words that signify race without direct reference to race. At the micro-level, racial projects are thought to become "common sense," reflected in the way that race is noticed in day to day interactions. In other words, "to see racial projects operating at the level of everyday life, we have only to examine the many ways in which, often unconsciously, we "notice' race" (Omi and Winant 1994:59); thus, 
Omi and Winant maintain that a project can be assumed to be racist "if and only if it creates and reproduces structures of domination based on essentialist categories of race" (Omi and Winant 1994:71, italics in original).

\section{Understanding Whiteness}

In their racial formation theory, Omi and Winant (1994) conceptualized the U.S. racial order as an "unstable equilibrium." Specifically, they argued that in times of contestation the state, alongside other social institutions, adapts either through accommodating the change or rigidly maintaining the status quo. As sociohistorical formations, racial formations originate in particular times and places. As such, race in the U.S. is embedded in a particular racial project constructing the most long-standing racial differences - that of blackness and whiteness.

While often overlooked, DuBois's ([1920]2004) essay "The Souls of White Folks" was the first sociological examination of white supremacy and white privilege. Long before Frankenberg's (1993) classic study of white women and Lipsitz's (1995) critique of the "possessive investment" of whiteness, DuBois critiqued the invisibility and universality of the "white race." Critical whiteness studies, as a branch of scholarship on race, began with Frankenberg's (1993) study of white women. Whiteness was largely conceptualized as a set of three interlocking components. First, whiteness was regarded as a structural position of racial privilege and power. Second, it was viewed as a standpoint from which white people understand themselves and others. Finally, it was considered a set of cultural practices that remains largely invisible (McIntosh 1998; Roediger 1991).

Because race is defined through difference, the emergence of whiteness as the standard through which other races would be understood constituted a particular racial project. Fields (1990) argued that the notion of race developed as an ideological justification for African slavery in the United States. Similarly, Harris (1992) argued that white identity and whiteness developed as a systematic response to the institution of slavery such that "whiteness was the characteristic, the attribute, the property of 
free human beings" (p. 1721). As a racial project, the construction of whiteness as a form of property not only separated Europeans from Africans, but it also helped establish a new racialhi erarchy.

More recently, scholarship on whiteness has reflected on its visibility rather than its invisibility. With the upsurge of diversity awareness and multi-cultural programs, whites can no longer avoid the privilege of their own skin color; thus, this crisis has resulted in the heightened visibility of white privilege (Gallagher 1995) and the extension of the "possessive investment" in whiteness (Lipsitz 1995). Winant (2001) suggested that a series of white racial projects have reinforced the power of whiteness. First, a neo-conservative project reframed race as a component of ethnicity. Additionally, racial politics has been reconceptualized under a colorblind, liberal individualist egalitarianism (Bonilla-Silva 2006). Second, a neo-liberal approach has argued that we must get "beyond" race. Couched in similar color-blind rhetoric, this liberal project attempts to obscure the reality of racial identities through a form of radical social constructionism. Finally, the new abolitionist project repudiates whiteness as a coherent racial identity. Much like Roediger's (1991) suggestion that whiteness is nothing more than oppressive and false, these new abolitionists take an apologetic stance towards white privilege without actually acknowledging the structural advantages whiteness brings.

While white racial hegemony has constructed whiteness as a largely "unnamed and unmarked" racial category, white racial projects ensure continued privilege for whites. For our purposes, we suggest that mass shootings represent a particular form of racial project that results in the differential representation of white and non-white shooters such that the raciality of whiteness and the privilege it contains remains intact.

\section{Racialization of Mass Shootings}

The loss of life, the tragic injuries, and the massive emotional impact that result from mass shootings are so devastating that it is easy to understand why those involved, as well as society as a whole, would want to move forward and put these tragedies behind them. It is easy to see why people might bristle at the suggestion that race 
is an important factor in understanding the way in which the public, the media, and government officials respond to these horrific acts of violence. When the perpetrator is identified as anything other than white, however, race suddenly takes front-stage in media and public discourse, belying the significance of race in ways that had previously remained invisible. Kobayashi and Peake (2000) contend that "so racialized is the development of American society that virtually no social analysis can take place without a recognition of this reality" (p. 392). Looking specifically at the Columbine shooting of 1999 in which two white students went on a shooting spree in their own school, killing thirteen and wounding 23 more, the authors examined the racialization that occurred in the aftermath of this tragedy that shook the small town of Littleton, Colorado. Following along the lines of Omi and Wynant (1994), Kobayashi and Peake (2000) define racialization as "the process by which racialized groups are identified, given stereotypical characteristics, and coerced into specific living conditions, often involving social/ spatial segregation and always constituting racialized places" ( $\mathrm{p}$. 393). The racial project unfolding here involves the denial that race played any part in the Columbine massacre as well as an emergent theme that the shootings were "an extremist act, completely out of the ordinary run of events, an aberration" (Kobayashi and Peake 2000:394, italics in original).

Because the Columbine shooters were both white, and because only one of the victims was African American, race was quickly dismissed as a relevant factor. The ability to summarily dismiss race results from a failure to recognize "white" as a race. Kobayashi and Peake (2000) argue that race is an important factor precisely because the massacre occurred in a predominately white town, in a predominately white school, by shooters who were themselves white. They contend that "Littleton's events were filtered through a normative white gaze that operated not by emphasizing racial difference, but by exercising the option to write 'race,' as well as alternate sexualities and other forms of deviance, out of the equation" (Kobayashi and Peake 2000:397). By denying race a role in the explanation for the unanticipated violence by two white boys, the hegemony of whiteness is reinforced, given a position of 
normalcy, and made invisible; thus, "it is the absence, rather than the presence, of racialized faces that is significant in understanding the events at Littleton" (Kobayashi and Peake 2000:393).

The racial project of mass shootings was further illustrated by the absence of race-talk in the aftermath of the Northern Illinois University (NIU) shooting in 2008. Jim Thomas, a professor at NIU who had mentored the man who would become the perpetrator of the shooting, notes that "mass school-shootings, for example, are interpreted by media or law enforcement by imposing prior narratives of new, similar events, and we analyze these by invoking a common vocabulary and shared methods" (Thomas 2008:110). By repeating perspectives popularized by previous shootings, particularly those that also involved white perpetrators, race continues to be marginalized out of existence, furthering the colorblind ideology of mass-shootings involving white perpetrators.

The "exceptions that prove the rule," of course, are those involving incidents where the shooter is identified as non-white. This occurred both at Virginia Tech and at Fort Hood where race suddenly become not only an issue, but one of such paramount importance that others who shared a racial identity with the perpetrator became victims of racial interpellation (Chong 2008; Hall 1980), forced to apologize or, worse, made to live in fear of retaliation.

The way in which this racial project is advanced is also demonstrated in the way that blame was attributed in disparate ways depending on the race of the shooters. White assailants are more likely than their non-white counterparts to be seen as deviant aberrations. Kimmel and Mahler (2003), who considered the role that homophobia plays in school shootings, also note that "as the shooters have become White and suburban middle-class boys, the public has shifted the blame away from group characteristics to individual psychological problems" (p. 1443). Even as Koreans felt some level of responsibility for the actions of the Virginia Tech shooter, and Arabs feared retribution for the actions of the Fort Hood shooter, whites were careful to disassociate themselves from the violence perpetrated by white shooters by labeling their actions as abnormal and pathological. The result is a racial project 
the simultaneously privileges whiteness and marginalizes nonwhiteness.

\section{The Benefits of Being White}

The very ability to eradicate race from any social discourse is a distinctly white privilege. Concomitant with this is the ability to redirect focus away from whites as a distinct population by pathologizing their aberrant behavior while reserving the right to generalize the abhorrent behavior of non-whites. By ignoring the existence of a "white" culture (Perry 2001), the overrepresentation of white shooters can be dismissed as abnormal behavior amidst an environment of normalcy. As a result, explanations for mass shootings are sought in a myriad of psycho-social factors without seriously considering the race of the perpetrator. Wise (2001) put it this way: "Indeed, every time media commentators discuss the similarities in these crimes they mention that the shooters were boys, they were loners, they got picked on, but never do they seem to notice a certain highly visible melanin deficiency" (p. 4). The ability to ignore race in describing mass shootings was evident in a fifty page report issued within a few years after the Columbine shooting (Verlinden, Hersen, and Thomas 2000). This report analyzed shooters from nine different rampages. Among all the risk factors considered in the report, race is never mentioned. The authors of the report completely ignored the fact that all of the shooters examined were white.

White privilege involves more than the ability to ignore race. It also controls the focus of official attention in crimes that involve white victims. Not only have most school shooters been white, but coming from predominately white social environments, their victims were mostly white as well. While carefully omitting overt discussions of race, the media nonetheless tends to give more coverage to tragedies that involved white victims (Lawrence and Mueller 2003). Ironically, the fact that most of the perpetrators are white fuels the rhetoric that these rampages are somehow anomalous, that they "tear apart the fabric of the American myth" (Aitken 2001:598). That so much attention is paid to the relatively rare violence that occurs in mass shootings has been cited as evidence 
of the "man-bites-dog" criterion of what is considered newsworthy. It has been said that "when a dog bites a person, nobody cares, but when the victim unexpectedly bites back, it's news!" (Lawrence and Mueller 2003:332). The shooting of whites by someone else who is also white is considered so out of the ordinary that it receives massive media and governmental attention while more mundane violence, an everyday occurrence in poor urban areas, is ignored and attributed to a culture of poverty (often read as Black or Latino culture). Because mass shootings by whites are rarer than the violence captured by news stories of blacks shooting blacks in urban ghettos, white communities become the norm where mass shootings can only be characterized as an anomaly. Meanwhile, inner-city communities with racial diversity are seen as the "other" where violence is simply accepted as status quo. Kobayashi and Peake (2000) contend that society needs to "recognize the ways in which the wider U.S. society glossed over this background, in both media coverage and everyday conversation, in order to focus upon the normalized whiteness of the community" (p. 393). They further illustrate their point by musing:

It is perhaps not pushing the point too far to suggest that if the events at Columbine had taken place in an urban school, or had the killers been black, the subsequent explanations, analyses, and stories would have been scripted differently. References to the very personal and aberrant characteristics of the shooters would have been replaced by more generalized, and more obviously racialized, representations of black American culture, epitomized by violence and "dysfunctional" family structures (Kobayashi and Peake 2000:396)

Similarly, Kimmel \& Mahler (2003) suggest that "If all the school shooters had been poor African American boys in inner-city schools, it is much less likely that their acts would have been seen as deviant or pathological"' (p. 1443).

Eric Harris and Dyland Klebold, the teenage boys responsible for the Columbine massacre, were described as antisocial, psychopathic, and loners (Langman 2009). The shock in the community was reflected in the belief that Littleton represented the 
traditional American landscape, the "mythic place of white middleclass America - suburbs, small towns, edge communities, country villages" (Aitken 2001:597). Harris and Klebold represented the antithesis of this community, portrayed as "aberrations, one-of-akind gothic-clad monsters" (Aitken 2001:594). Steve Kazmierczak, the man who returned to Northern Illinois University to execute his killing spree, was initially thought to be a model student, being a Dean's award winner. He was viewed as a normal young man. Subsequent investigations revealed a different picture, one that portrayed Kazmierczak as very disturbed person who "possessed another side, one that few people noticed" (Thomas 2008:111). Media accounts obsessed over his history of psychiatric problems, drawing considerable attention to the fact that he had recently stopped taking psychotropic medication and had recently acquired several disturbing tattoos depicting violent characters from the movie, "Saw" (Thomas 2008; Vann 2008). David Van (2008), a writer and professor at the University of San Francisco, summed up this paradox in the opening lines of his exposé in Esquire magazine: "We were told that Steven Kazmierczak, who killed five students and then himself at Northern Illinois University in February, was a sweet, unassuming, overachieving grad student who inexplicably snapped. He was not" (p. 114). In both of these incidents, race is carefully omitted as a relevant factor. They were, after all, white perpetrators who shot randomly, impacting mostly white victims. White privilege, then, allowed the discourse to be shifted away from a generalized social problem associated with race, to one of personal issues representing individualized pathologies.

\section{Marginalization of Other}

Robert Park (1950), an early pioneer of race studies, described what he called the "marginal man." The fundamental notion behind the study of the marginal man is "the conviction that the individual's personality, while based on instincts, temperament and the endocrine balance, achieves its final form under the influence of the individual's conception of himself' (Park 1950:375). Theories of assimilation place immigrants into this category of the marginal man, one who occupies a place somewhere between foreigner and 
citizen. Bonilla-Silva (2004) suggests that some immigrants will achieve the status of "honorary white" while others will remain relegated to positions of inferiority. Tuan (1998), however, argues that regardless of how close non-white immigrants may come to achieving "whiteness," they will nonetheless remain "forever foreigners," existing in society without the privileges enjoyed by whites. Specifically, she suggests that although Asian-Americans may have reached the status of honorary white, they continue to experience a great deal of violence and discrimination, and thus, they remain forever foreigners. According to Kim (1999), AsianAmericans are racially triangulated against both Whites and Blacks. She notes that this racial triangulation is advantageous for Whites because it allows them to criticize and dismantle programs such as affirmative action without accusations of racism.

This in-between position of Asian-Americans is clearly illustrated in public responses to the Virginia Tech shooting, perpetrated by Korean-born Seung-Hui Cho. Although it was quickly evident that Cho suffered from mental problems, his psychotic diatribe, broadcasted on television and repeated ad nauseum over the internet, did not successfully shift the discourse away from the fact that he was Korean:

Asian American anxieties prompted by the Virginia Tech shootings are more complex than a mere case of mistaken identity. They are also prompted by the fear of racialization itself, for having one's racial particularity called out in the public sphere. In this case, the call, 'Look, an Asian!" my have originally targeted Cho in the media spotlight, but in fact addresses any Asian American who recognizes him or herself by that racial label. (Chong 2008:32-33)

Asian-Americans caught in the status of "forever foreigners" found themselves not only fearing retaliation for the Virginia Tech attack but actually apologizing for it. Without the protections afforded by white privilege, the racial project of mass shootings left Koreans unable to either shift the focus of the attack away from race or successfully pronounce pathological issues suffered by the shooter 
as the sole cause of his actions. Instead, the model-minority status of Asian-Americans that often allows them to remain invisible in a white-dominated society was instantly shattered, leaving AsianAmericans and specifically, Koreans, defenseless against the distrustful gaze of a white America. In response, "they apologize[d] not only for Cho's actions, but for being Asian American in a society that demands the erasure of racial difference for the full assumption of rights" (Chong 2008:36).

Arab Americans, too, find themselves in an "in-between" racial position, classified as "not only above African and Asian Americans ... but also below 'white' people" (Barrett and Roediger 1997:2). While officially classified as white and marginally American, they are still not granted the full privileges associated with being white. Although the "in-between" state described by Barrett \& Roediger (1997) suggests a temporary state, one that can eventually be overcome as one is fully accepted as white, both Bonilla-Silva (2004) and O'Brien (2008) argue that this honorary white or forever foreigner status is more permanent, suggesting that the privileges of 'whiteness' remains largely out of reach for those not-quite-white immigrants.

It is into this category that Arab Americans fall (Abdulrahim 2008; Dualteri 2008).

In the years following World-War II, the relationship between the U.S. and the Middle East intensified. As a result, Arabs were racialized as culturally barbaric and predisposed to violence and terrorism (Cainkar 2008). On September 11, 2001, individuals identified as Arab Muslims hijacked five airplanes, crashing them into the Twin Towers in New York and the Pentagon in Washington, D.C. In response to these attacks the United States instituted a series of policies that targeted Arabs, including Arab Americans. This, in turn, caused religion, specifically the Muslim religion, to be further conflated with race in the minds of the American public. Research has shown that Arab Americans who identify as Christian, as opposed to Muslim, are less likely to report incidents of discrimination following the events of 9/11 (Read 2008). Muslims, on the other hand, are much more likely to acknowledge higher rates of discrimination. Arabs were thus subjected to a dichotomous 
gaze in the United States as either "good Arabs" or "bad Arabs." To be viewed as "good"

Arab political culture... and the political aspects of cultural forms, must be suppressed whenever these entail vigorous criticism of Israel or express solidarity with those who resist U.S. imperial projects in the Middle East.... In the simplest terms, domestic recognition as 'good Arabs' is granted in exchange for acquiescence in matters of U.S. foreign policy. (Shryock 2008:108)

To an American public that has but a rudimentary understanding of foreign cultures as well as little understanding of religions that fall outside of Christianity to be Arab and Muslim is to be a "bad Arab."

Before Nidal Malik Hasan began firing at Fort Hood army base in November of 2009, he reportedly shouted the words "Allahu Akbar," which translates to "God is Great." This phrase is known as the takbir and is used by Muslims to express a wide range of emotions (TMG 2009). Although investigations concluded that the gunman acted alone, the incident prompted immediate accusations of terrorism with Senator Joseph Lieberman calling it "the most destructive terrorist attack on America since September 11, 2001" (AFP 2009). Little was said about the mental health of Hassan, a licensed psychiatrist. What details were released about his personal history focused mainly on his religious connections and convictions. Conflating religion with race, the public once again cast a suspicious eye on Arabs, eliciting fear of retaliation and continued discrimination. Arab Americans, despite their official designation as white, were unable to evoke white privilege in order to shift the focus away from Arabs as a race and onto Hassan as an individual with obvious mental issues. As with the Virginia Tech shooting, the racial project of mass shootings insists that race play a central role in the explanation at Fort Hood.

\section{Conclusion}

When people are killed by senseless violence, we are left feeling 
helpless. When the senseless violence is committed by someone from the same social group as his victims, we are left wondering why. In seeking answers, the race of the perpetrator plays an important, though often covert, role. Through the process of racial formation, race is either totally erased from official and media accounts of the shootings or else takes center stage as a fundamental issue. Drawing on white privilege, a privilege so taken-for-granted that it is virtually unrecognized by its beneficiaries, focus is diverted from the race of white shooters. Instead, these individuals are labeled as aberrations, anomalies within society, or psychopaths who represent the antithesis of mainstream America. Without the benefits of white privilege, shooters who are not white are forever doomed to be the blackguards of their race, a permanent shadow to those who bear a cultural or phenotypical similarity. In short, whites are able to successfully disassociate themselves from massacres perpetrated by whites, whereas non-whites feel obligated to apologize for crimes committed by someone from their race or to be vigilant against potential irrational retaliation or retribution from a color-blind public who nonetheless seems unable to distinguish between a mass murderer and someone who bears some resemblance to that murderer.

Most mass shootings that have occurred since the 1966 massacre at the University of Texas have been committed by white males. Shootings in which the perpetrator was not white stand out as notable exceptions. By looking at official and media reactions of four separate shootings, two committed by whites and two by nonwhites, we have suggested that a racial project, as defined by Omi and Wynant's (1994) racial formation theory, has systematically, albeit covertly and perhaps unconsciously, erased race as a salient topic in the former incidents while simultaneously emphasizing race as a critical issue in the latter attacks. The Columbine shooting and the Northern Illinois University shooting were both committed by white perpetrators, although no white groups apologized and no white groups expressed concern for retaliation or retribution. The attacks at both Virginia Tech and Fort Hood, on the other hand, involved non-white assailants and evoked fear of retribution in Koreans and Arabs, respectively, and in the case of the former, 
prompting an official apology. Although this paper merely suggests a racial project, a deeper analysis of all mass shootings and examination of official and media responses to each is required to further illuminate the racial project. If, as intimated in this paper, it is shown that race is virtually eliminated as a salient issue in each of the shootings that involve white perpetrators while race is made the central issue in each of those committed by non-white shooters, then it would be quite difficult, if not illogical, to deny the existence of a racial project advanced by a hegemonic white America and intended to systematically control the importance of race when trying to make sense of mass shootings in the United States. ite Denial." Multicultural Perspectives 3:3-4.

\section{References}

Abdulrahim, Sawsan. 2008. "Whiteness" and the Arab Immigrant Experience." Pp. 131-146 in Race and Arab Americans Before and After 9/11: From Invisible Citizens to Visible Subjects, edited by A. Jamal and N. Naber. Syracuse, NY: Syracuse University Press.

AFP. 2009, “Army base shooting was 'terrorist attack': US lawmaker", Retrieved November 28, 2009.

Aitken, Stuart C. 2001. "Schoolyard shootings: Racism, sexism, and moral panics over teen violence." Antipode 33:593-600.

Barrett, James R. and David R. Roediger. 1997. "Inbetween Peoples: Race, Nationality and the" New Immigrant" Working Class." Journal of American Ethnic History:3-44.

Bonilla-Silva, Eduardo. 2004. "From bi-racial to tri-racial: Towards a new system of racial stratification in the USA." Ethnic and Racial Studies 27:931-950.

Bonilla-Silva, Eduardo. 2006. Racism without racists: Color-blind racism and the persistence of racial inequality in the United States: Rowman $\&$ Littlefield Pub Inc.

Cainkar, Louise. 2008. "Thinking Outside the Box: Arab Americans and U.S. Racial Formations." Pp. 46-80 in Race and Arab Americans before and after 9/11: from invisible citizens to visible subjects, edited by A. Jamal and N. Naber. Syracuse, NY: Syracuse University Press. Chong, Sylvia Shin Huey. 2008. “'Look, an Asian!': The Politics of Racial Interpellation in the Wake of the Virginia Tech Shootings." Journal of Asian American Studies 11:49. 
Cornell, Stephen E. and Douglas Hartmann. 2006. Ethnicity and race: Making identities in a changing world. Thousand Oaks, CA: Pine Forge Press.

Dao, James. 2009, "Suspect Was 'Mortified' About Deployment “, Retrieved November 25, 2009 (http://www.nytimes.com/2009/11/06/ us/06suspect.html? $\mathrm{r}=1$ ).

Du Bois, W.E.B. [1920]2004. Darkwater: Voices from within the Veil. New York: Washington Square Press.

Dualteri, Sarah A. 2008. "Strange Fruit? Syrian Immigrants, Extralegal Violence, and Racial Formation in the United States." Pp. 147-169 in Race and Arab Americans Before and After 9/11: From Invisible Citizens to Visible Subjects, edited by A. Jamal and N. Naber. Syracuse, NY: Syracuse University Press.

Fields, Barbara J. 1990. "Slavery, race and ideology in the United States of America." New Left Review 181:95-118.

Frankenberg, Ruth. 1993. White women, race matters: The social construction of whiteness. Minneapolis, MN: University Of Minnesota Press.

Gallagher, Charles A. 1995. "White reconstruction in the university." Socialist Review 24:165-187.

Hall, Stuart. 1980. "Articulation and Societies Structured in Dominance." Sociological theories, race and colonialism:305-345.

Harris, Cheryl I. 1992. "Whiteness as property." Harv. L. Rev. 106:1707. Hong, Adrian. 2007, “Koreans Aren't to Blame”, Retrieved May 10, 2010 (http://www.washingtonpost.com/wp-dyn/content/article/2007/04/19/ AR2007041902942_pf.html).

Kim, Claire Jean. 1999. "The racial triangulation of Asian Americans." Politics and Society 27:105-138.

Kimmel, Michael S. and Matthew Mahler. 2003. "Adolescent masculinity, homophobia, and violence: Random school shootings, 1982-2001." American Behavioral Scientist 46:1439.

Kobayashi, Audrey and Linda Peake. 2000. "Racism out of place: thoughts on whiteness and an antiracist geography in the new millennium." Annals of the Association of American Geographers 90:392-403.

Kolchak, Carl. 2006, "Charles Whitman-The Texas Tower Massacre", Retrieved November 26, 2009 (http://www.associatedcontent. com/article/20857/charles whitmanthe texas tower_massacre. html?cat=49).

Langman, Peter. 2009. Why kids kill: Inside the minds of school shooters. New York: Palgrave MacMillan. 
Lawrence, Richard and David Mueller. 2003. "School Shootings and the Man-Bites-Dog Criterion of Newsworthiness." Youth Violence and Juvenile Justice 1:330-345.

Lipsitz, George. 1995. "The possessive investment in Whiteness: Racialized social democracy and the" White" problem in American studies." American Quarterly:369-387.

McIntosh, Peggy. 1998. "White privilege: Unpacking the invisible knapsack." Race, class, and gender in the United States: An integrated study 4:165-169.

Montagu, Ashley. 1962. "The concept of race." American Anthropologist:919-928.

Nagel, Joane. 1994. "Constructing ethnicity: Creating and recreating ethnic identity and culture." Social Problems:152-176.

Newman, Katherin S. and Cybelle Fox. 2009. "Repeat Tragedy: Rampage Shootings in American High School and College Settings, 20022008." American Behavioral Scientist 52:1286.

Newman, Katherin S., Cybelle Fox, David J. Harding, Jal Mehta, and Wendy Roth. 2004. Rampage: The social roots of school shootings. New York: Basic Books.

O'Brien, Eileen. 2008. The Racial Middle: Latinos and Asian Americans Living Beyond the Racial Divide. New York: New York University Press.

Omi, Michael and Howard Winant. 1994. Racial Formation in the United States: From the 1960s to the 1990s: Routledge.

Park, Robert Ezra. 1950. "Cultural Conflict and the Marginal Man." Pp. 372-376 in Race and culture. New York: Free Press.

Perry, Pamela. 2001. "White means never having to say you're ethnic." Journal of Contemporary Ethnography 30:56.

Read, Jen'nan Ghazal. 2008. "Discrimination and Identity Formation in a Post-9/11 Era: A Comparison of Muslim and Christian Arab Americans." Pp. 305-317 in Race and Arab Americans before and after 9/11: from invisible citizens to visible subjects, edited by A. Jamal and N. Naber. Syracuse, NY: Syracuse University Press.

Roediger, David R. 1991. The wages of whiteness: Race and the making of the American working class. New York: Verso Books.

Ross, Sherwood. 2009, "Gun Violence Shows Now Signs of Abating", Retrieved November 25, 2009 (http://pubrecord.org/nation/6072/ violence-shows-signs-abating/).

Shryock, Andrew. 2008. "The Moral Anaologies of Race: Arab American Identity, Color Politics, and the Limits of Racialized Citizenship." 
Pp. 81-113 in Race and Arab Americans before and after 9/11: from invisible citizens to visible subjects, edited by A. Jamal and N. Naber. Syracuse, NY: Syracuse University Press.

Stein, Sam 2009, "Muslim, Arab Groups Condemn Fort Hood Shooting, Brace For Backlash", Retrieved November 25, 2009 (http://www.huffingtonpost.com/2009/11/05/muslim-arab-groupscondem n $347777 . \mathrm{html})$.

Thomas, Jim. 2008. "Nietzsche at Northern: An Existential Narrative of Confronting the Abyss." Social Psychology Quarterly 71:109-113.

TMG. 2009, "Fort Hood shootings: the meaning of "Allahu Akbar", Retrieved November 28, 2009 (http://www.telegraph.co.uk/news/ worldnews/northamerica/usa/6516570/Fort-Hood-shootings-themeaning-of-Allahu-Akbar.html).

Tuan, Mia. 1998. Forever foreigners or honorary whites?: Rutgers University Press New Brunswick, NJ.

Van den Berghe, Pierre. 2001. "Does race matter." Race and racism:101-113. Vann, David. 2008. "Portrait of the School Shooter as a Young Man." Esquire Magazine, August, pp. 114-126.

Verlinden, Stephanie, Michel Hersen, and Jay Thomas. 2000. "Risk factors in school shootings." Clinical Psychology Review 20:3-56.

Winant, Howard. 2000. "Race and race theory." Annual Review of Sociology 26:169-185.

Winant, Howard. 2001. "The making and unmaking of whiteness." in The making and unmaking of whiteness, edited by B. B. Rasmussen, E. Klinenberg, I. J. Nexica, and M. Wray. Durham \& London: Duke University Press Books.

Wise, Tim. 2001. "School Shootings and White Denial." Multicultural Perspectives 3:3-4. 
